\title{
In Vitro Impact Preliminary Assessment of Airborne Particulate from Metalworking and Woodworking Industries
}

Ilona Pavlovska ( $\square$ ilona.pavlovska@rsu.Iv)

Riga Stradins University: Rigas Stradinas Universitate https://orcid.org/0000-0002-9295-6768

Anna Ramata-Stunda

University of Latvia: Latvijas Universitate

Zanna Martinsone

Riga Stradins University: Rigas Stradinas Universitate

Martins Boroduskis

University of Latvia: Latvijas Universitate

Liene Patetko

University of Latvia: Latvijas Universitate

Inese Martinsone

Riga Stradins University: Rigas Stradinas Universitate

Anita Seile

Riga Stradins University: Rigas Stradinas Universitate

Ivars Vanadzins

Riga Stradins University: Rigas Stradinas Universitate

\section{Research}

Keywords: in vitro exposure, EpiAirway ${ }^{\mathrm{TM}}$, A549 cells, airborne particulate, 3D tissue models, respiratory epithelial tissues, alternative testing strategies

Posted Date: June 30th, 2021

DOI: https://doi.org/10.21203/rs.3.rs-612755/v1

License: (c) (i) This work is licensed under a Creative Commons Attribution 4.0 International License. Read Full License 


\section{Abstract}

\section{Background}

Inhalation is the main route of exposure to airborne pollutants. To evaluate the safety and assess the risks of occupational hazards different testing approaches are used. 3D airway epithelial tissues allow to mimic exposure conditions in vitro, generates human-relevant toxicology data, allows to elucidate mode of action of pollutants.

Results

Gilian 3500 pumps equipped with Standard Midget Impingers were used to collect the airborne particulate from woodworking and metalworking environments. EpiAirway ${ }^{\mathrm{TM}}$ tissues were used to model half working day (4 h), full working day (8 h), and 3 working day exposures to occupational pollutants. Tissue viability was assessed using MTT assay. RT-qPCR analyses performed to analyze the expression of gelsolin, caspase-3, and IL-6. Tissue morphology was assessed by hematoxylin/eosin staining. Acute exposure to workspace pollutants slightly affected tissue viability and did not change the morphology. Both types of particles suppressed expression of gelsolin, with metalworking samples showing the most pronounced effect. A slight reduction in caspase-3 expression was observed. Particles from metalworking suppressed IL-6 expression.

\section{Conclusion}

3D Epithelial tissues can be used to model exposures to airborne pollutants. Exposure to particles from woodworking and metalworking had a minor effect on tissue viability but affected the expression of inflammation and apoptosis-related genes.

\section{Introduction}

Inhalation is a primary exposure route for humans, where the respiratory tract is the target tissue or portal of entry for the systemic circulation for inhaled substances. To evaluate the safety of specific compounds, particles, or mixtures, inhalation exposure studies need to be performed. Inhalation toxicology studies have relied on in vivo and in vitro testing to investigate the toxicity of air pollutants. While animal models for inhalation exposure and toxicology studies are still considered the standard, there is a growing demand for alternative testing strategies (Zavala et al., 2017). Demand for alterative tests is driven by the $3 \mathrm{R}$ principle: the replacement, reduction, and refinement of animal usage. Moreover, species-specific differences can have important implications in inhalation toxicity testing humans.

Several inhalation toxicity studies in rodents have been proven to lack relevance to humans (Mowat et al., 2017).

Human-relevant in vitro models allow us to reproduce the distinctive properties of the human airway epithelium. Cell and tissue-based assays are used for inhalation toxicity studies. Immortalized cell lines 
are also widely used, with the A549 cell line, derived from adenocarcinomic alveolar basal epithelial cells, being the most popular. Other examples of cell lines from the respiratory tract that are commonly used include the human cells lines BEAS-2B and Calu-3 and the rodent cell lines LA-4 and MHS. In past studies, primary cells from human donors, including nasal and bronchial epithelial cells, as well as lung macrophages, were used to examine inhalation toxicology. However, cell-based test systems have several disadvantages. Transformed and immortalized cell lines respond differently from primary cells and may produce irrelevant results. Moreover, monocell cultures that are grown while submerged in a cultivation medium have difficulty closely mimicking in vivo situation (Upadhyay and Palmberg, 2018; Hiemstra et al., 2018; Zavala et al., 2016).

Over the last decade, 3D airway epithelial tissue models have gained acceptance as relevant test systems. Studies have shown that these 3D cell structures represent more physiologically relevant conditions than monocell cultures. To overcome the limitations of animal studies and tests in submerged cell cultures, commercially available airway tissue models have been developed. The MucilAir (Epithelix Corp., Geneva, Switzerland) and EpiAirway (MatTek Corp, Ashland, Massachusetts, USA) systems are examples of commercial airway tissue models that are currently used in research. Both the Mucilair and EpiAirway systems are 3D tissue models reconstituted using primary human respiratory epithelial cells (Rothen-Rutishauser et al., 2008; Zavala et al., 2020). These 3D tissue models are predominantly used in toxicology studies and safety assessments of new materials, including nanomaterials, chemical compounds, drugs, and e-cigaretes (Fields et al., 2017; Czekala et al., 2019; Jackson et al., 2018; Chapman et al., 2013).

Air pollution with particulate matter is among the largest inducers of negative health effects. Particulate matter is a complex mixture of chemical compounds and biological components. Depending on the source, it varies in its composition, particle size, particle count, and surface area. Fine, ultrafine, and nanoparticles, when inhaled, are able to penetrate deep into the airways and generate negative effects, including the production of oxidative stress and the induction of inflammation. In the airways, the primary targets that particles interact with are epithelial cells and macrophages. However, interactions with other immune cells, endothelial cells, and neurons have also been reported. Apoptosis or programmed cell death is one of the consequences resulting from exposure to air pollutants. Different mechanisms of cytotoxicity and apoptosis induction after exposure to airborne particles have been proposed, including the production of reactive oxygen species, impaired mitochondrial functions, the activation of enzymes involved in apoptosis progression, and inflammation (Andreau et al., 2012; Dagher et al., 2006; Ovrevik et al., 2015; Pardo et al., 2020; Peixoto et al., 2017).

The goal of the current work was to show the applicability of a tissue based test system for in vitro assessment of the effects of airway exposure to particulate pollutants in a working environment.

\section{Materials And Methods}

\subsection{Collection and measurement of the particles.}


Airborne particulates from an $8 \mathrm{~h}$ work shift were collected from around the working zones close to the workers in two environments: the metalworking industry (M), to assess the processes related to welding (shielded metal arc welding) and milling, in which many particles are released in the nanoscale range ( $<$ $100 \mathrm{~nm}$ ), and the woodworking industry (W), where grinding and polishing processes were used to assess organic particles. The size, shape, quantity, and chemical compositions of nanoparticles were detailed in previous work on the occupational exposure parameters for the characterization of nanoparticulate matter toxicity and a comparison of the biological markers in aerosol-weighed workplaces (Pavlovska et al., 2016; Pavlovska et al., 2019; Livak and Schmittgen, 2001). These studies showed the presence of all three types of dust, microscopic, ultramicroscopic, and nanometric (< $100 \mathrm{~nm}$, containing inorganic and organic dusts, as well as toxic elements like $\mathrm{Zn}, \mathrm{Si}, \mathrm{Fe}, \mathrm{Mn}$, and $\mathrm{Cr}$ ). The smallest detected median diameters of the particles $(12 \mathrm{~nm})$ and the smallest differences between inhalable dust and the nanosized particle number and mass concentrations were observed in the occupational air of wood industry workplaces.

\subsection{Effects on proliferation of lung epithelial cells}

Human lung epithelial cell line A549 (ATCC, CCL-185) was used to evaluate nanoparticles' effects on cell proliferation. Cells were seeded on 96-well microplates (Sarstedt) at density of 3500 cells per well in Dulbecco's modified Eagle's Medium (Biochrom) supplemented with $100 \mathrm{U} / \mathrm{ml}$ penicillin, $100 \mu \mathrm{g} / \mathrm{ml}$ streptomycin (Gibco) and $10 \%$ fetal bovine serum (Gibco) and cultivated at $37^{\circ} \mathrm{C}, 5 \% \mathrm{CO}_{2}$. After seeding, cells were left to adhere for $24 \mathrm{~h}$. Cell medium was removed and the $100 \mu \mathrm{L}$ of fresh medium containing nanoparticle suspensions was added. Cells were incubated with nanoparticles for $96 \mathrm{~h}$ and monitored during this period with IncuCyte ZOOM live cell imaging system (Essen Biosciences). Using integrated phase contrast microscopy images of cell cultures were taken and recorded once per hour. Kinetics of cell growth was analyzed using the IncuCyte integrated confluence algorithm, where confluence is a surrogate for cell number. Data were obtained from three biological replicates.

\subsection{Tissue culture.}

EpiAirway ${ }^{\text {TM }}$ 3D human respiratory epithelial tissues (AIR-100, surface area $0.6 \mathrm{~cm}^{2}$ ) were purchased from MatTek Corporation (Ashland, MA, USA). The tissues were cultivated at the air-liquid interface in an AIR100-ASY medium (MatTek) in all exposure experiments. Immediately after arrival, tissue inserts were transferred to 6-well plates containing $1 \mathrm{ml}$ fresh culture medium (AIR-100-ASY, MatTek) and equilibrated for 18 hours at $37^{\circ} \mathrm{C}$ and $5 \% \mathrm{CO}_{2}$. Prior to application of the test samples, the tissue culture inserts were placed on special holders, and $5 \mathrm{ml}$ of fresh basolateral culture medium was added.

\subsection{Collection and application of test samples}

The airborne particulates from the wood processing and metalworking environments were collected by Gilian 3500 pumps in $5 \mathrm{ml}$ sterile water using suitable receivers (Standard Midget Impingers).

After collection, the samples were freeze-dried (used a lyophilisator Christ Alpha 2-4LD plus). The mass of the freeze-dried particles was determined, and they were resuspended in a sterile phosphate buffered 
solution ( $\mathrm{pH} \mathrm{7,4} \mathrm{(hereafter} \mathrm{PBS,} \mathrm{Biochrom,} \mathrm{Germany))} \mathrm{so} \mathrm{that} \mathrm{one} \mathrm{dose} \mathrm{to} \mathrm{be} \mathrm{applied} \mathrm{on} \mathrm{the} \mathrm{tissue} \mathrm{culture}$ (.e.g., $25 \mu \mathrm{L}$ ) would contain a two-fold theoretical concentration of particles in contact with the airway epithelia during a 4-hour working period.

To expose the EpiAirway ${ }^{\text {TI }}$ tissues, samples of the particles were collected from the wood processing industry (volume of air pumped was 122.4 litres, particle concentration of $1.397 \mathrm{mg} / \mathrm{m}^{3}$ ) and the metalworking industry (volume of air pumped was 106.3 litres, particle concentration of $1.018 \mathrm{mg} / \mathrm{m}^{3}$ ). Assuming that the average volume of inhaled air per minute under moderate physical activity is $46 \mathrm{~L} / \mathrm{min}$ (minute volume limits of $37.3-54.7 \mathrm{~L} / \mathrm{min}$, as described in the literature), it is estimated that during 4 hours work, the wood worker's airway epithelium will be exposed to $15.42 \mathrm{mg}$ air-polluting particles, while the metalworking worker will be exposed to $11.24 \mathrm{mg}$. Since the surface area of the EpiAirway tissue culture is approximately $1.7 \times 10^{4}$ times smaller than the surface area of adult airways, to model exposure over a $4 \mathrm{~h}$ period, $0.925 \mathrm{mg}$ polluting particles must be taken from the woodworking industry and $0.674 \mathrm{mg}$ from the metalworking industry. To ensure uniform application of the concentration of the

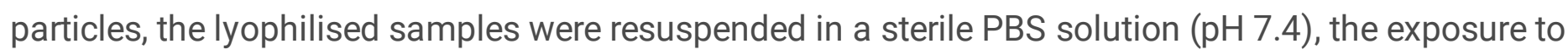
which could be ensured by applying $25 \mu \mathrm{L}$ of suspension per application to the apical surfaces of the tissues. Before adding them to the tissues to ensure smooth suspension of the particles, dust samples were treated with an ultrasound for 1 minute and then vortexed for 1 minute.

\subsection{Exposure of EpiAirway tissues with polluting particles}

Prior to their application, the polluting particle samples were sonicated for 1 minute. The apical surface of the EpiAriway tissues was rinsed with PBS to remove mucus. A total of $25 \mu \mathrm{L}$ particle suspension was added to the apical surface of the tissues. To simulate short term (half working day), full working day, and three-day exposure, the EpiAirway tissues were treated with samples of the polluting particles for different time periods. The periods were chosen to evaluate the short-term exposure ( $4 \mathrm{~h})$, exposure to a polluted working environment during a full work shift $(8 \mathrm{~h})$, and prolonged ( 3 working days) exposure to a polluted working environment $(72 \mathrm{~h})$. Particles were applied to the tissues and incubated for 4 hours,

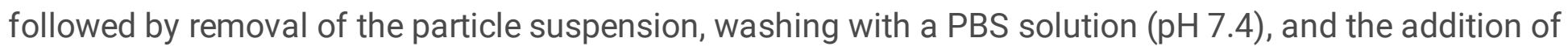
a fresh particle suspension. After the second 4-hour incubation, the apical surface was washed and incubated for $16 \mathrm{~h}$ without the addition of the test samples.

To simulate the "daily rest period", after two $4 \mathrm{~h}$ incubation periods with airborne particles, the tissues were incubated overnight ( $16 \mathrm{~h}$ ) without the application of polluting particles. The incubation and rest cycles were repeated after $16 \mathrm{~h}$ of the rest regime until a $72 \mathrm{~h}$ exposure period was reached. All incubations were done at $37^{\circ} \mathrm{C}$ and $5 \% \mathrm{CO}_{2}$ (see the experimental design of the EpiAirway exposure to particle samples in Fig. 1).

Tissues were collected after $4 \mathrm{~h}, 8 \mathrm{~h}$, and $72 \mathrm{~h}$ incubation periods to perform a cell viability analysis, isolate the RNA for gene expression analysis, and perform histological analyses. The tissue culture distribution by group is shown in Table 1 . 
Table 1

Distribution of tissue cultures by incubation time with the test particle suspensions and their further use for analysis.

\begin{tabular}{|lllllll|}
\hline $\mathbf{4 h}$ & & $\mathbf{8 h}$ & & $72 \mathrm{~h}$ & \\
\hline $\mathrm{CG}^{1}$ & $\mathrm{CG}^{2}$ & $\mathrm{CG}^{1}$ & $\mathrm{CG}^{2}$ & $\mathrm{CG}^{1}$ & $\mathrm{CG}^{2}$ & Color description \\
$\mathrm{W}^{1}$ & $\mathrm{~W}^{2}$ & $\mathrm{~W}^{1}$ & $\mathrm{~W}^{2}$ & $\mathrm{~W}^{3}$ & $\mathrm{~W}^{2}$ & Histology \\
$\mathrm{W}^{3}$ & $\mathrm{M}^{1}$ & $\mathrm{~W}^{3}$ & $\mathrm{M}^{1}$ & $\mathrm{~W}^{1}$ & $\mathrm{M}^{1}$ & MTT test \\
$\mathrm{M}^{2}$ & $\mathrm{M}^{3}$ & $\mathrm{M}^{2}$ & $\mathrm{M}^{3}$ & $\mathrm{M}^{2}$ & $\mathrm{M}^{3}$ & Gene expression analysis \\
\hline
\end{tabular}

W - woodworking industry; M - metalworking industry; C - control group.

1,2,3 - additional description to colors: 1 - MTT test; 2 - histology; 3 - gene expression analysis.

\subsection{MTT tissue viability assay}

The 3-(4,5-dimethylthiazol-2-yl)-2,5-diphenyltetrazolium bromide (MTT) and extractant reagents were supplied as a kit (MatTek) and prepared following the supplier's recommendations. The EpiAirway tissues were transferred to 24-well culture plates containing $300 \mu \mathrm{L}$ MTT reagent per well and incubated in a $37^{\circ} \mathrm{C} 5 \% \mathrm{CO}_{2}$ incubator for 3 hours. Following incubation, the EpiAirway tissues were submerged in 2.0 $\mathrm{mL}$ MTT extractant solution (MatTek). Tissues were then extracted in the dark at room temperature for 16 hours. After extraction, $200 \mu \mathrm{L}$ of extractant from each tissue was transferred to a clear 96 -well plate, and absorbance was measured at $570 \mathrm{~nm}$ with the background at $650 \mathrm{~nm}$ subtracted. The absorption readings of the control tissue culture (to which no solution containing the pollutants was applied) were taken as $100 \%$, and the viability of the treated tissues was calculated as a percentage of the control level by dividing the sample absorbance values by the control absorbance.

\subsection{Assessment of the effects on gene expression in tissue}

The relative changes in gene expression were analysed using a quantitative real-time reverse transcription polymerase chain reaction (qPCR) to assess the effects of air-polluting particles on the expression of three selected genes. EpiAirway tissues were lysed using a Trizol LS reagent (Invitrogen, USA), and RNA was extracted from the cell lysate. Isolated RNA was quantified using Nanodrop ND-100, and $500 \mathrm{ng}$ of RNA was used for the synthesis of complementary DNA (cDNS) using the First Strand cDNA Synthesis Kit (ThermoScientific, USA).

cDNA samples were amplificated using SYBR Green qPCR Master Mix (Thermo Scientific, US) and an ABI Prizm 7300 analyser (Applied Biosystems, USA). Reactions were incubated for 10 minutes at $95^{\circ} \mathrm{C}$ followed by 40 cycles of 15 seconds at $95^{\circ} \mathrm{C}$ and 1 minute at $60^{\circ} \mathrm{C}$. The relative changes in gene expression were analyzed by the comparative cycle threshold method $\left(2^{-\triangle \triangle C T}\right)$ and using the GAPDH gene as in (Yacobi et al., 2011). The primers used to amplify genes of interest are listed in Table 2. 
Table 2

Primers used for gene expression analyses.

\begin{tabular}{|c|c|c|c|}
\hline Gene & Forward primer & Reverse primer & $\begin{array}{l}\text { Product } \\
\text { length }\end{array}$ \\
\hline $\begin{array}{l}\text { GAPDH } \\
\text { (NM } \\
001357943.2)\end{array}$ & TCCCTGAGCTGAACGGGAAG & GGAGGAGTGGGTGTCGCTGT & 218 bp \\
\hline $\begin{array}{l}\text { Gelsolin } \\
\text { (NM } \\
\text { 001258029.2) }\end{array}$ & TGGAGGCGACAGCTACATCA & СTCCTTGCCTTGGACCACAC & $187 \mathrm{bp}$ \\
\hline $\begin{array}{l}\text { Caspase-3 } \\
\text { (NM 004346.4) }\end{array}$ & GCCTGCCGTGGTACAGAACT & ATGGCACAAAGCGACTGGAT & $182 \mathrm{bp}$ \\
\hline $\begin{array}{l}\text { IL-6 } \\
\text { (NM 000600.5) }\end{array}$ & TCGAGCCCACCGGGAACGAA & GCAGGGAAGGCAGCAGGCAA & $137 \mathrm{bp}$ \\
\hline
\end{tabular}

\subsection{Histological analysis}

For the histological analysis, tissues were fixed in $10 \%$ formalin for 30 minutes at room temperature and rinsed with PBS. The fixed tissue samples were dehydrated using a series of increasing ethanol concentrations cleared with xylene, infiltrated with paraffin, and embedded in paraffin blocks. Tissues were cut using a Leica microtome (sample thickness: $5 \mu \mathrm{m}$ ). Tissue sections were then mounted on a slide, and the prepared slides were kept at $40^{\circ} \mathrm{C}$ until dry. The deparaffinization of samples was carried out using xylene/ethanol. The deparaffinized slides were stained with hematoxylin/eosin and viewed using a Leica DM2000 microscope.

\section{Results And Discussion}

\subsection{Effects on proliferation of lung epithelial cells}

Collected nanoparticle samples were tested for their effects on viability and proliferation of lung epithelial cell line A549. Two different nanoparticle concentrations, 125 and $250 \mu \mathrm{g} / \mathrm{ml}$, from both industries were tested to evaluate if subtoxic concentrations of nanoparticles over $96 \mathrm{~h}$ period. Results show that nanoparticles at tested concentrations does not have cytotoxic effect on A549 cells. The rate of proliferation in presence of nanoparticles is similar to that of control (Fig. 2).

\subsection{Impact on the viability of tissues.}

To evaluate the effects of workspace air polluting particles on the viability of the airway epithelia, an MTT assay was used. Tissues were treated apically with particle suspensions to mimic half working day ( $4 \mathrm{~h})$, full working day (8 h), and three working day (72 h) exposures. 
Effects on tissue viability varied among exposure times and the sources of the polluting particles (Fig. 3). No statistically significant changes were observed for tissue viability $(n=3)$. Gene epxression analyses did not have biological replicates due to limited availability of tissues $(n=1)$.

After $4 \mathrm{~h}$ exposure to particles from the woodworking industry, a slight increase in tissue viability was still observable. This might be due to the specific stimulation of cell metabolism by particles and the induction of the expression of MTT reducing enzymes. On the contrary, exposure to particles from the metalworking industry slightly reduced tissue viability (by $11.34 \%$ compared to the control) within the $4 \mathrm{~h}$ incubation period. Differences in the immediate effects after short-term exposure can be explained by the chemical compositions and sizes of the polluting particles from the two workspaces. Different cytotoxicity results have been reported from studies on various nanoparticles, indicating that the effects on the viability of airway tissues depend strongly on the physiochemical properties of the particles (Maniatis et al., 2009). The air polluting particles from the metalworking industry contained higher concentrations of ultramicroscopic and nanometric particles than woodworking. Differences in chemical composition were also observed (Pavlovska et al., 2016).

In the case of an 8-hour exposure, a pronounced reduction in tissue viability was observed after incubation with particles from the woodworking industry, indicating that negative effects can be expected when exposing the airway epithelium to these types of air-polluting particles for a full working day. Exposure to particles form metalworking for $8 \mathrm{~h}$ did not affect tissue viability. This could be explained by the ability of airway epithelial cells to overcome the stress initially caused by the addition of polluting particles. Surprisingly, after exposing tissues to the particles from woodworking for three $8 \mathrm{~h}$ cycles, the tissue viability remained unchanged. This indicates that the air-polluting particles from the woodworking company have a more pronounced short-term (acute) cytotoxic effect, but epithelial cells are able to overcome these negative effects over longer exposure. Sixteen hours rest periods between $8 \mathrm{~h}$ exposures might be sufficient for the cellular recovery process. For the air samples from the metalworking industry, exposure to polluting particles for three $8 \mathrm{~h}$ periods resulted in slightly reduced tissue viability (by 10.64 $\%$, indicating the potential long-term negative effects of the airborne metalworking pollutants. In this case, the tissues were able to overcome any temporary adverse effects, but in the longer term, the negative effects accumulated.

Overall, the results indicate that polluting particles from the woodworking and metalworking industries do not induce pronounced acute cytotoxic effects. However, the different results from exposures to samples from these two industries indicate the sensitivity of the tissue-based test system in evaluating acute effects.

\subsection{Effects on gene expression.}

Tissue samples from the simulation of a full working day $(8 \mathrm{~h})$ of exposure to particles from the woodworking and metalworking industries were used to isolate the RNA and analyse changes in gene expression. 
The results show that after $8 \mathrm{~h}$ incubation with particles, the expression of all three analysed genes was suppressed (Fig. 4). For both tested types of polluting particles, gelsolin gene expression was the most suppressed. Suppression was more pronounced for metalworking particles ( $34.15 \%$ of the control level), although after $8 \mathrm{~h}$ exposure, the viability of the tissues was at the control level $(\mathrm{n}=3$ (technical replicates) for viability, $n=1$ for gene expression). For woodworking, gelsolin expression was $50.17 \%$ of the control level. Gelsolin is an actin remodeling protein that has been reported to play a role in stress response, exert antioxidative and wound healing activities, and regulate apoptosis in airway tissues. There are contradictory data about the role of gelsolin in response to airway damage, and its role has yet to be confirmed. Some reports indicate decreased levels of gelsolin in lung injury and inflammatory diseases, while others have shown that gelsolin expression is upregulated in the case of airway damage (Gupta et al., 2019; Vaid et al., 2020; Koya et al., 2000; Kobayashi et al., 2015). Our previous studies on the expression of gelsolin in employees of the woodworking and metalworking industries agree with these results: Gelsolin gene expression was suppressed compared to office employees (Pavlovska et al., 2016). The repression of gelsolin expression after exposure and the agreement with data from industry employees provide a basis for further studies on particles' effects on gelsolin expression.

Similar changes in the expression of the caspase-3, a protease involved in apoptosis, were observed for both industries. Particulate pollutants from woodworking reduced expression by $21 \%$, while those from metalworking reduced expression by $20.73 \%$. Some reports in the literature focus on induced caspase-3 gene coding for protease activation and apoptosis in human lung epithelial cells after short-term exposure (24-72 h) to airborne particulate matter Dagher et al., 2006). Our preliminary data, however, indicate that airborne particles have a negligible effect on the expression of this apoptotic protein.

Further, to elucidate its effects on apoptosis, caspase-3 expression and activity at the protein level should be analyzed. There are differences in the present results compared to the expression of caspase- 3 that was observed previously in industry workers; here, expression was slightly suppressed, while previous studies showed increase in woodworking industry employees but suppression in metalworking employees (Pavlovska et al., 2016). Changes in caspase-3 expression might be more pronounced after chronic exposure.

The expression of the IL- 6 gene was slightly reduced ( $84.09 \%$ of the control) compared to the control for the particles from the woodworking industry, while more pronounced suppression ( $46.01 \%$ of the control) of this gene was observed after exposure to particles from the metalworking industry. These differences in expression might be due to different effects resulting from the various sizes and chemical compositions of the particle samples. IL-6 plays a pleiotropic role: It acts both as an inflammatory cytokine and as a mediator in various recovery and regeneration processes; its role in environmental pollutant-induced inflammation has been previously described (Rincon and Irvin, 2012; Yu et al., 2002; Paplińska-Goryca et al., 2013). The expression of IL-6 varies in different parts of the airways (PaplińskaGoryca et al., 2013). The suppression of IL-6 may, therefore, have a positive effect, indicating the tissue's ability to suppress excessive inflammation in response to particles. It might also have a negative impact on tissue recovery. These results are opposite to those from studies of nanomaterials, where the expression of IL-6 was increased in a 3D airway model after acute exposure (Skuland et al., 2020); the 
results are also different from the expression levels of industry workers. Previous studies on IL-6 levels showed that in woodworking employees, IL-6 expression is increased, but in metalworking employees, the expression levels were similar to those of office workers (Pavlovska et al., 2016). Differences between various studies and our results could be explained by exposure times. Analysis of protein levels were not performed in this study, but it would enrich research data regarding to tissue responses explanation better and could be provided during next research stages.

\subsection{Assessment of the impact on tissue culture structures}

Histological cuts were prepared and analysed to assess the impact of the pollutants on the tissue's structure and morphology. All resulting tissue sections showed structures and cells specific to respiratory epithelial tissues (several layers of epithelial cells, the accumulation of mucus in the apical part of the tissue, and the presence of cilia). The histological sections stained with haematosilin are shown in Fig. 5.

Histological sections show that although the negative effects of the tested particles were potentially observed at the cell metabolism (MTT test) and molecular level (gene expression), the morphology of the tissues was not affected.

\section{Conclusions}

Our study confirms that 3D airway epithelial tissues can be used as a relevant system to model exposure to workspace pollutants and evaluate their effects. The polluting particles tested in this study show minor effects on viability of A549 cells and EpiAirway tissues and tissue morphology after a short period of exposure. Particles from different working environments affect the expression of gelsolin and IL- 6 genes differently. It should be emphasized that the most suppressed gelsolin gene was also reduced among the employees from both industries in our previous studies, highlighting this protein as a potential marker for occupational pollutant effects on airway tissues.

\section{Declarations}

- Ethical Approval and Consent to participate

Not applicable

- Consent for publication

No personal information is included in this study

- Availability of data and materials

All data analyzed within this study are included in the manuscript

- Competing interests 
The authors have no competing interests to declare

- Funding

This work was supported by ESF project "Development of up-to-date diagnostic and research methods for the risks caused by nanoparticles and ergonomic factors at workplaces" Agreement No.

2013/0050/1DP/1.1.1.2.0/13/APIA/VIAA/025

- Authors' contributions

Ilona Pavlovska: Writing - original draft, Conceptualization, Investigation, Anna Ramata-Stunda: Investigation, Data curation, Resources, Writing - review \& editing, Zanna Martinsone: Data curation, Supervision, Writing - review \& editing, Martins Boroduskis: Formal analysis, Visualization, Liene Patetko: Formal analysis, Visualization, Ivars Vanadzins: Funding acquisition, Project administration, Supervision, Anita Seile: Methodology, Validation, Inese Martinsone: Resources, Data curation.

The manuscript was written through the contributions of all authors. All authors have approved the final version of the manuscript

- Acknowledgements

Not applicable

- Authors' information

Ilona Pavlovska - Institute of Occupation Safety and Environmental Health, Laboratory of Hygiene an Occupatioanl Deseases, Riga Stradins University, Riga, Latvia, ilona.pavlovska@rsu.Iv

Anna Ramata-Stunda - Laboratory of Bioanalytical and Biodosimetry Methods, Faculty of Biology, University of Latvia, Riga, Latvia, ramata.stunda@gmail.com

Zanna Martinsone - Institute of Occupation Safety and Environmental Health, Laboratory of Hygiene an Occupatioanl Deseases, Riga Stradins University, Riga, Latvia, zanna.martinsone@rsu.Iv

Martins Boroduskis - Laboratory of Bioanalytical and Biodosimetry Methods, Faculty of Biology, University of Latvia, Riga, Latvia, martins.boroduskis@lu.Iv

Liene Patetko - Laboratory of Bioanalytical and Biodosimetry Methods, Faculty of Biology, University of Latvia, Riga, Latvia, liene.patetko@gmail.com

Inese Martinsone - Institute of Occupation Safety and Environmental Health, Laboratory of Hygiene an Occupatioanl Deseases, Riga Stradins University, Riga, Latvia, inese.martinsone@rsu.Iv

Anita Seile - Institute of Occupation Safety and Environmental Health, Laboratory of Hygiene an Occupatioanl Deseases, Riga Stradins University, Riga, Latvia, anita.seile@rsu.Iv 
Ivars Vanadzins - Institute of Occupation Safety and Environmental Health, Riga Stradins University, Riga, Latvia, ivars.vanadzins@rsu.Iv

- Correspondence to Ilona Pavlovska ilona.pavlovska@rsu.Iv

\section{Acknowledgements}

This work was supported by ESF project "Development of up-to-date diagnostic and research methods for the risks caused by nanoparticles and ergonomic factors at workplaces" Agreement No. 2013/0050/1DP/1.1.1.2.0/13/APIA/VIAA/025.

\section{References}

1. Andreau K., Leroux M., and Bouharrour A. Health and Cellular Impacts of Air Pollutants: From Cytoprotection to Cytotoxicity. Biochemistry Research International, 2012, Article ID 493894, 18 pages. doi:10.1155/2012/493894

2. Chapman K.L., Holzgrefe H., Black L.E., Brown M., Chellman G., Copeman C., Couch J., Creton S., Gehen S., Hoberman A. Pharmaceutical toxicology: designing studies to reduce animal use, while maximizing human translation. Regul. Toxicol. Pharmacol., 66, pp. 88-103, 2013. doi:10.1016/j.yrtph.2013.03.001

3. Czekala L., Simms L., Stevenson M., Tschierske N., Maione A.G., Walele T. Toxicological comparison of cigarette smoke and e-cigarette aerosol using a 3D in vitro human respiratory model. Regulatory Toxicology and Pharmacology 103, pp. 314-324, 2019. doi.org/10.1016/j.yrtph.2019.01.036

4. Dagher Z., Garcon G., Billet S., Gosset P., Ledoux F., Courcot D., Aboukais A., Shirali P. Activation of different pathways of apoptosis by air pollution particulate matter (PM2.5) in human epithelial lung cells (L132) in culture. Toxicology 225, pp. 12-24, 2006. doi:10.1016/j.tox.2006.04.038

5. Fields W., Maione A., Keyser B. and Bombick B. Characterization and Application of the VITROCELL VC1 Smoke Exposure System and 3D EpiAirway Models for Toxicological and e-Cigarette Evaluations. Applied in Vitro Toxicology 3(1), 2017. doi: 10.1089/aivt.2016.0035

6. Gupta A.K., Chopra B.S., Vaid B., Sagar A., Raut S., Badmalia M.D., Khatri N. Protective effects of gelsolin in acute pulmonary thromboembolism and thrombosis in the carotid artery of mice. PLoS ONE 14(4), pp. 1-14, 2019. doi.org/10.1371/journal.pone.0215717

7. Hiemstra P.S., Grootaers G., van der Does A.M., Krul C.A.M., Kooter I.M. Human lung epithelial cell cultures for analysis of inhaled toxicants: Lessons learned and future directions. Toxicology in Vitro 47, pp. 137-146, 2018. doi.org/10.1016/j.tiv.2017.11.005

8. Jackson G.R. Jr, Maione A.G., Klausner M., Hayden P.J. Prevalidation of an Acute Inhalation Toxicity Test Using the EpiAirway In Vitro Human Airway Model. Appl In Vitro Toxicol. 4(2), pp. 149-158, 2018. doi:10.1089/aivt.2018.0004

9. Kobayashi T., Tanaka K., Fujita T., Umezawa H., Amano H., Yoshioka K., Naito Y., Hatano M., Kimura S., Tatsumi K. and Kasuya Y. Bidirectional role of IL-6 signal in pathogenesis of lung fibrosis. 
Respiratory Research 16(99), 2015. doi:10.1186/s12931-015-0261-z

10. Koya R.C., Fujita H., Shimizu S., Ohtsu M., Takimoto M., Tsujimoto Y., and Kuzumaki N. Gelsolin Inhibits Apoptosis by Blocking Mitochondrial Membrane Potential Loss and Cytochrome c Release. J. Biol. Chem. 275(20), pp.15343-15349, 2000. doi: 10.1074/jbc.275.20.15343.PMID10809769

11. Livak K.J. and Schmittgen T.D.. Analysis of relative gene expression data using real-time quantitative PCR and the 2(-Delta Delta C(T)) Method. Methods. 25(4), pp. 402-408, 2001.

doi:10.1006/meth.2001.1262

12. Maniatis N.A., Harokopos V., Thanassopoulou A., Oikonomou N., Mersinias V., Witke W., Orfanos S.E., Armaganidis A., Roussos C., Kotanidou A. and Aidinis V. A Critical Role for Gelsolin in VentilatorInduced Lung Injury. Am. J. Respir. Cell. Mol. Biol. 41. pp. 426-432, 2009. doi: 10.1165/rcmb.2008$01440 \mathrm{C}$

13. Mowat V., Alexander D. J., and Pilling A.M. A Comparison of Rodent and Nonrodent Laryngeal and Tracheal Bifurcation Sensitivities in Inhalation Toxicity Studies and Their Relevance for Human Exposure. Toxicologic Pathology 45(1), pp. 216-222, 2017. doi: 10.1177/0192623316678695

14. Ovrevik J., Refsnes M., Leg M., Holme J.A. and Schwarze P.E. Activation of Proinflammatory Responses in Cells of the Airway Mucosa by Particulate Matter: Oxidant- and Non-Oxidant Mediated Triggering Mechanisms. Biomolecules 5, pp. 1399-1440, 2015. doi:10.3390/biom5031399

15. Paplińska-Goryca M., Nejman-Gryz P., Chazan R. and Grubek-Jaworska H. The expression of the eotaxins IL- 6 and CXCL8 in human epithelial cells from various levels of the respiratory tract. Cell Mol Biol Lett. 18(4), pp. 612-630, 2013. doi:10.2478/s11658-013-0107-y

16. Pardo M., Qiu X., Zimmermann R. and Rudich Y. Particulate Matter Toxicity Is Nrf2 and Mitochondria Dependent: The Roles of Metals and Polycyclic Aromatic Hydrocarbons. Chem Res Toxicol. 33(5), pp. 1110-1120, 2020. doi:10.1021/acs.chemrestox.0c00007

17. Pavlovska I., Martinsone Ž., Ramata-Stunda A., Vanadzins I., Martinsone I., Seile A. Comparison of biological markers in aerosol-weighed workplaces. J. Nanopart. Res. 21(138), 2019. doi.org/10.1007/s11051-019-4578-22019

18. Pavlovska I., Martinsone Z., Vanadzins I., Martinsone I., Seile A., Sudmalis P. Occupational exposure parameters for characterization of nanoparticulate matter toxicity: Metal versus wood processing. Process Safety and Environmental Protection, pp. 230-237, 2016. doi.org/10.1016/j.psep.2016.03.018

19. Peixoto M.S., de Oliveira Galvão M.F. and Batistuzzo de Medeiros S.R.. Cell death pathways of particulate matter toxicity. Chemosphere. 188, pp. 32-48, 2017. doi:10.1016/j.chemosphere.2017.08.076

20. Rincon M. and Irvin C.G. Role of IL-6 in asthma and other inflammatory pulmonary diseases. Int J Biol Sci. 8(9), pp. 1281-1290, 2012. doi:10.7150/ijbs.4874

21. Rothen-Rutishauser B., Blank F., Mühlfeld C., and Gehr P. In vitro models of the human epithelial airway barrier to study the toxic potential of particulate matter. Expert Opin. Drug Metab. Toxicol. 4(8), pp. 1075-1090, 2008. doi: 10.1517/17425250802233638 
22. Skuland T., Låg M., Gutleb A.C. et al. Pro-inflammatory effects of crystalline- and nano-sized noncrystalline silica particles in a 3D alveolar model. Part Fibre Toxicol. 17(1), pp. 13, 2020. doi:10.1186/s12989-020-00345-3.

23. Upadhyay S. and Palmberg L. Air-liquid interface: Relevant in vitro models for investigating air pollutant-induced pulmonary toxicity. Published by Oxford University Press on behalf of the Society of Toxicology, pp. 1-25, 2018. doi/10.1093/toxsci/kfy053/4925479

24. Vaid B., Chopra B.S., Raut S., Sagar A., Badmalia M.D., and Khatri N.. Antioxidant and Wound Healing Property of Gelsolin in. Oxidative Medicine and Cellular Longevity Article ID 4045365, pp.1-7, 2020. doi.org/10.1155/2020/4045365

25. Yacobi N.R., Fazllolahi F., Kim Y.H., Sipos A., Borok Z., Kim K.J. and Crandall E.D. Nanomaterial interactions with and trafficking across the lung alveolar epithelial barrier: implications for health effects of air-pollution particles. Air quality, atmosphere, \& health. 4(1), pp. 65-78, 2011. https://doi.org/10.1007/s11869-010-0098-z

26. Yu M., Zheng X., Witschi H. and Pinkerton K.E. The Role of Interleukin-6 in Pulmonary Inflammation and Injury Induced by Exposure to Environmental Air Pollutants, Toxicological Sciences, 68(2), pp. 488-497, 2002. https://doi.org/10.1093/toxsci/68.2.488

27. Zavala J., Freedman A.N., Szilagyi J.T., Jaspers I., Wambaugh J.F., Higuchi M. and Rager J.E. New Approach Methods to Evaluate Health Risks of Air Pollutants: Critical Design Considerations for In Vitro Exposure Testing. Int. J. Environ. Res. Public Health, 17, 2124, pp. 1-28, 2020. doi:10.3390/ijerph17062124

28. Zavala J., O'Brien B., Lichtveld K., Sexton K.G., Rusyn I., Jaspers I. and Vizuete W. Assessment of Biological Responses of EpiAirway ${ }^{\text {TM }} 3$-D Cell Constructs vs. A549 Cells for Determining Toxicity of Ambient Air Pollution. Inhal Toxicol. 28(6), pp. 251-259, 2017. doi:10.3109/08958378.2016.1157227

29. Zavala J., O'Brien B., Lichtveld K., Sexton K.G., Rusyn I., Jaspers I., and Vizuete W. Assessment of biological responses of EpiAirway 3-D cell constructs versus A549 cells for determining toxicity of ambient air pollution. Inhal Toxicol. 28(6), pp. 251-259, 2016. doi:10.3109/08958378.2016.1157227

\section{Figures}




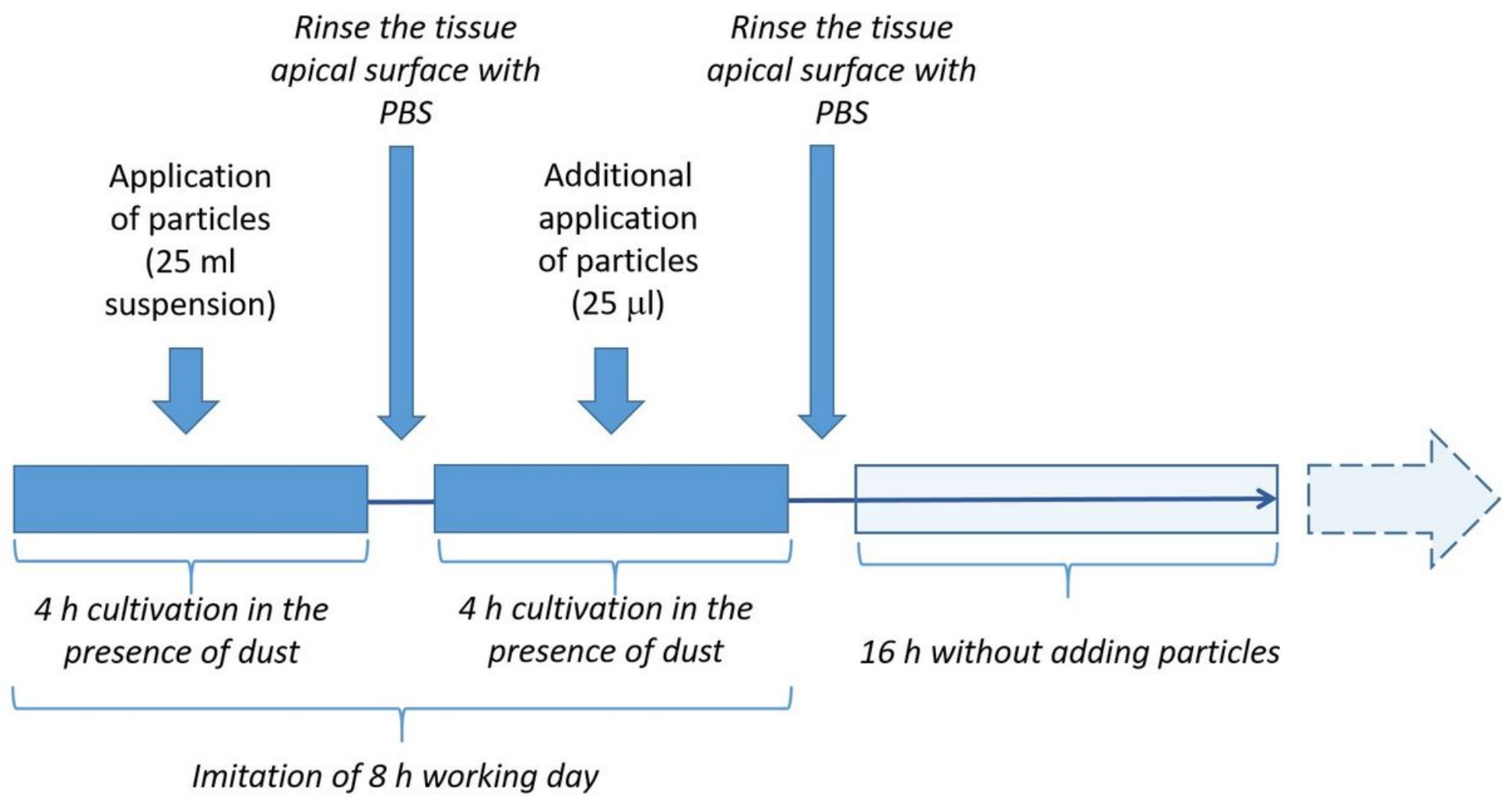

Figure 1

Plan for the in vitro testing of airborne particles in EpiAirway tissue cultures. 


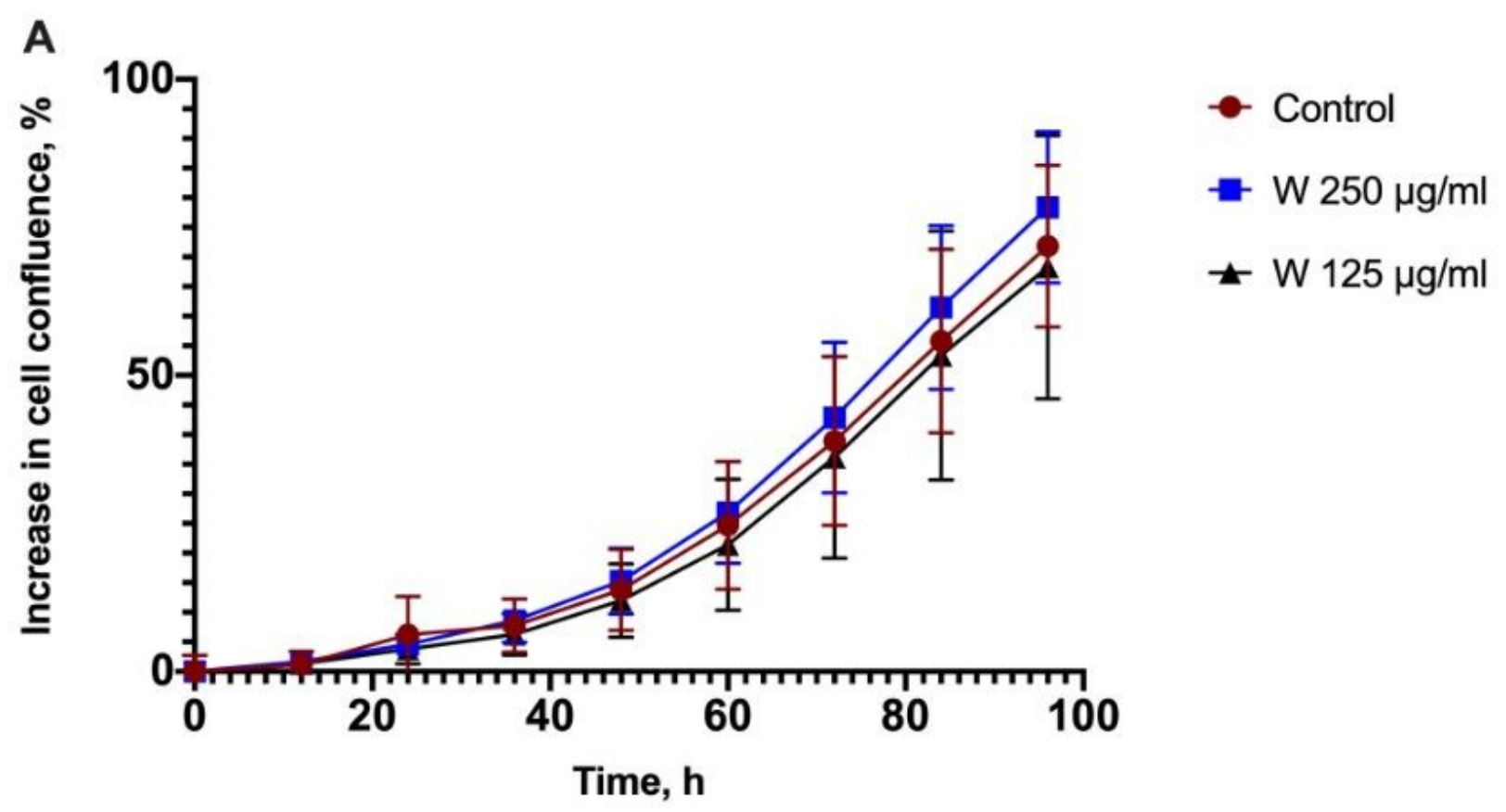

B

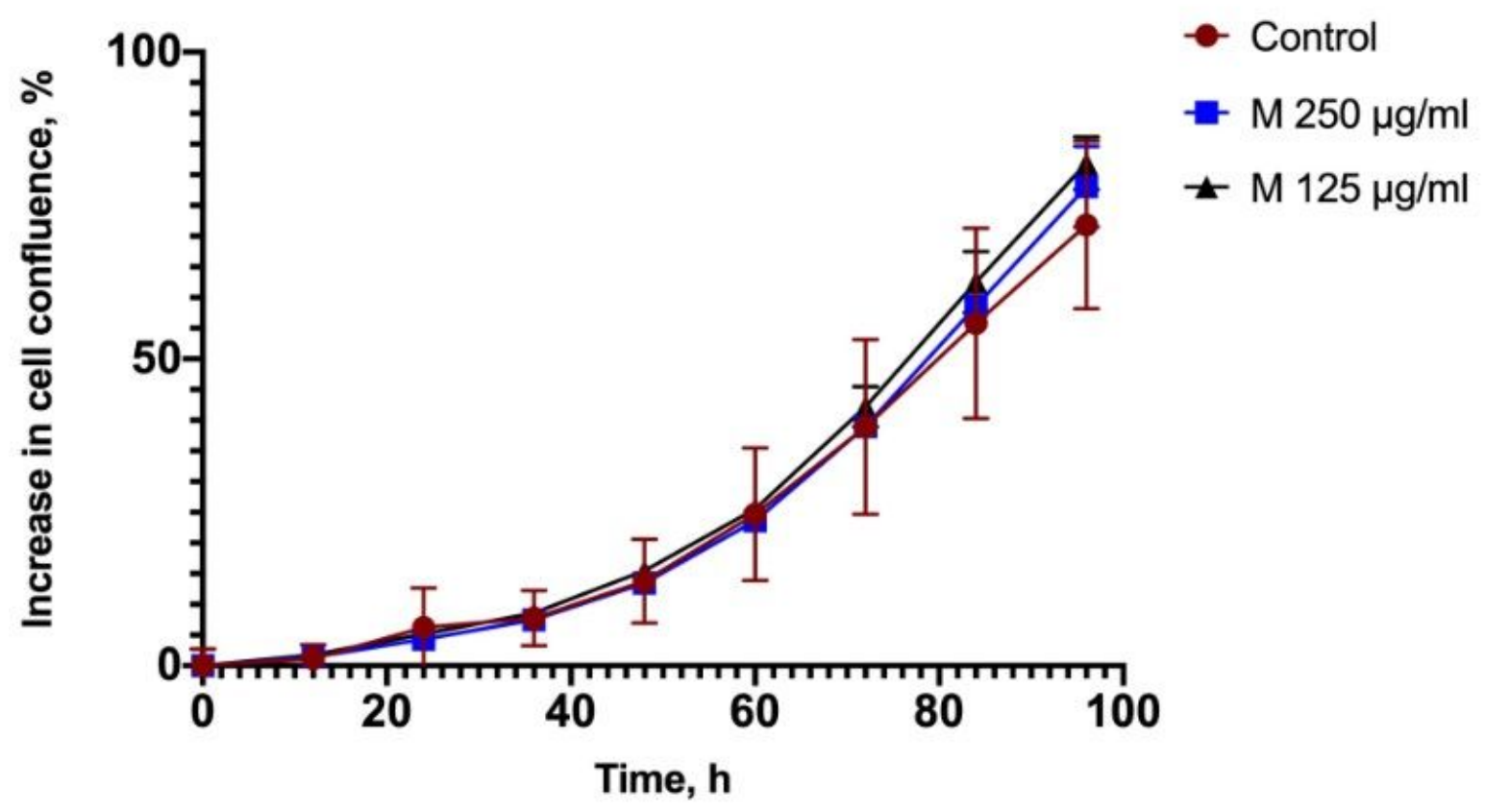

Figure 2

Effects of airborne nanoparticles on proliferation of lung epithelial cell line A549. A - nanoparticles from woodworking $(W)$ industry, $B$ - nanoparticles from metalworking $(M)$ industry. $N=3$. 


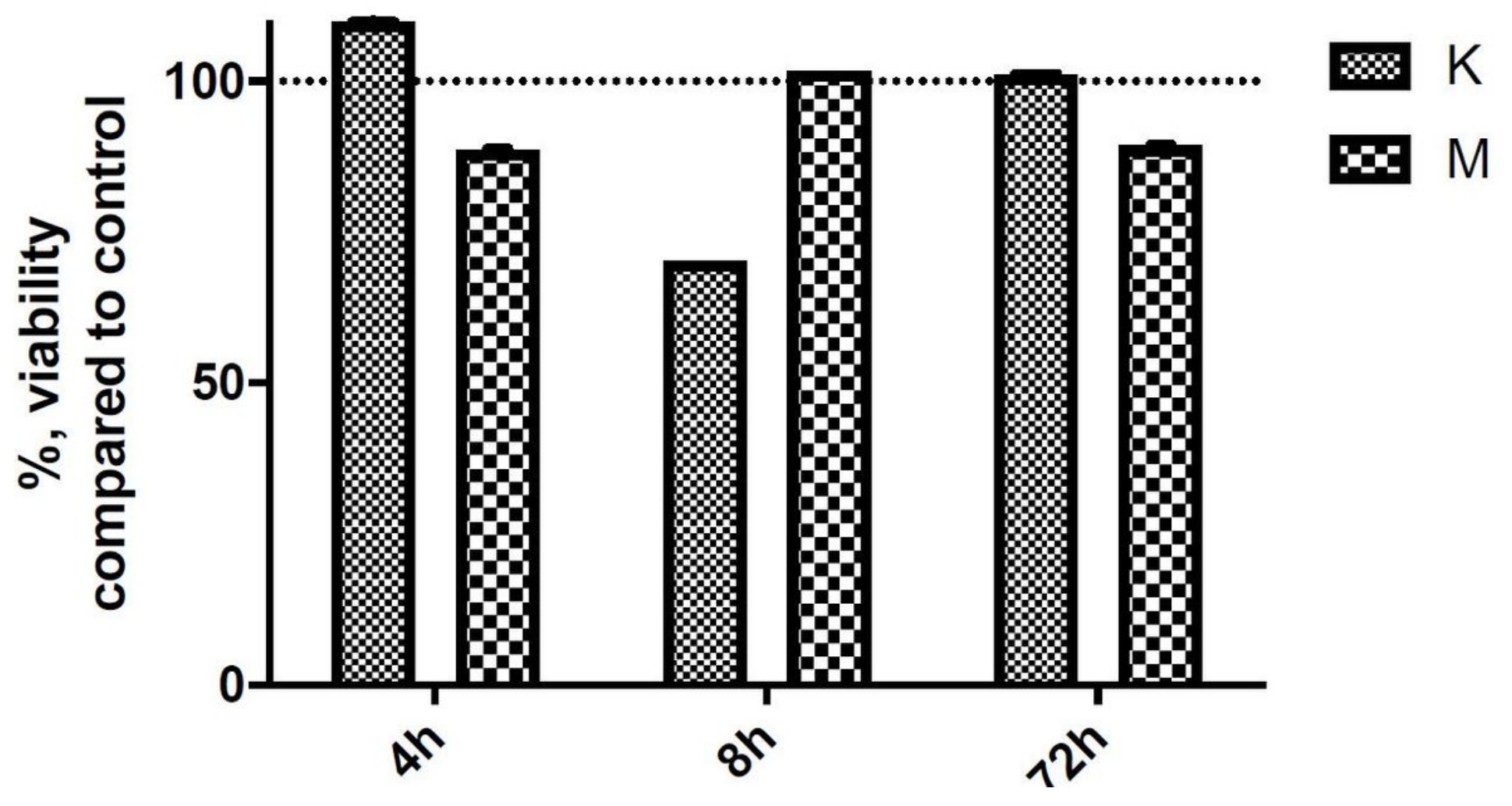

Figure 3

The effect of particles on the viability of the EpiAirway tissue depending on the exposure time. Airborne particles collected from the woodworking industry $(\mathrm{W})$ and metalworking industry $(\mathrm{M})$. The dashed line indicates the control level. 


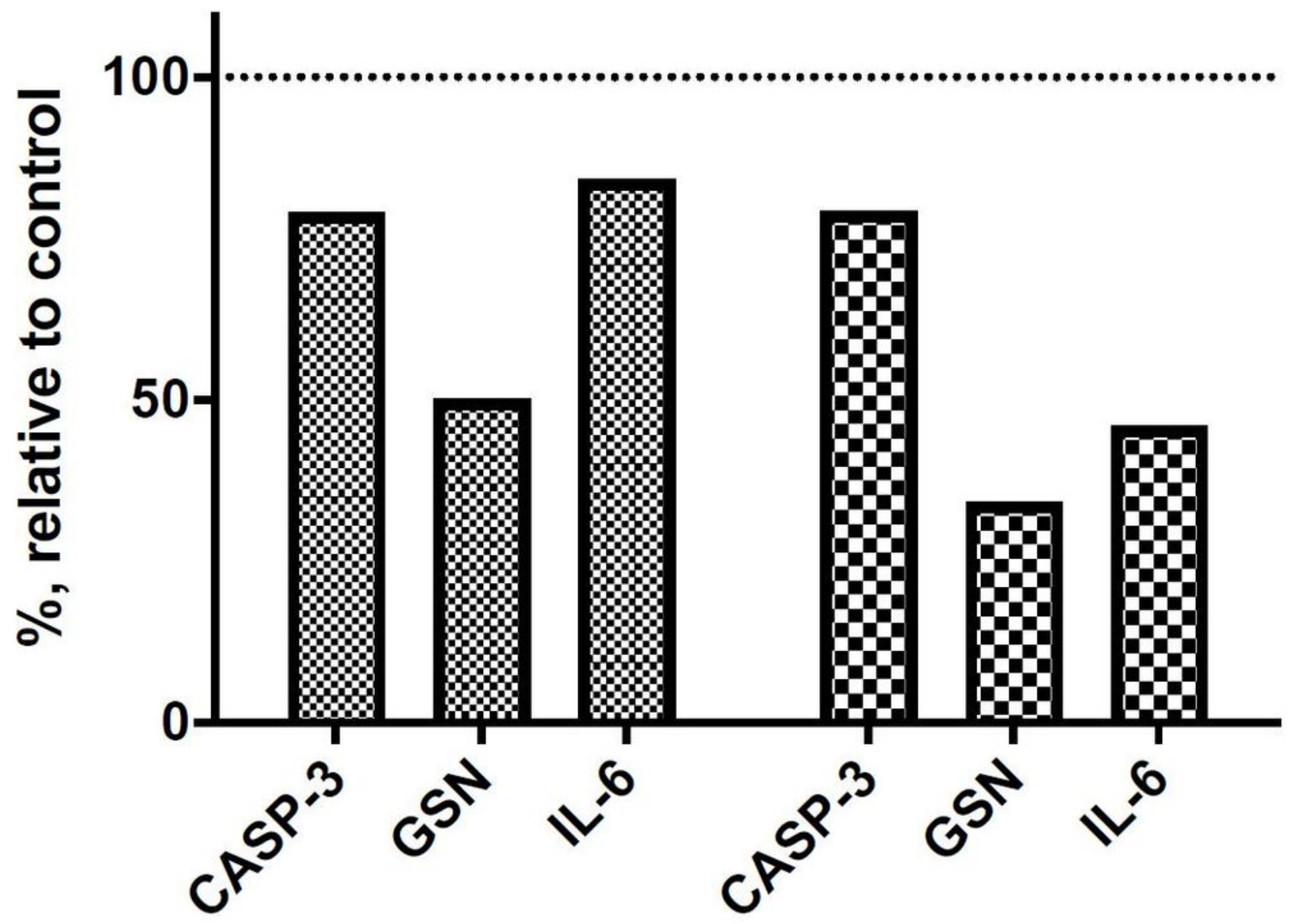

Figure 4

Relative changes in gene expression of the EpiAirway tissues after $8 \mathrm{~h}$ incubation with air-polluting particles. Airborne particles collected from the woodworking industry (W) and metalworking industry (M). The dashed line indicates the control level. 

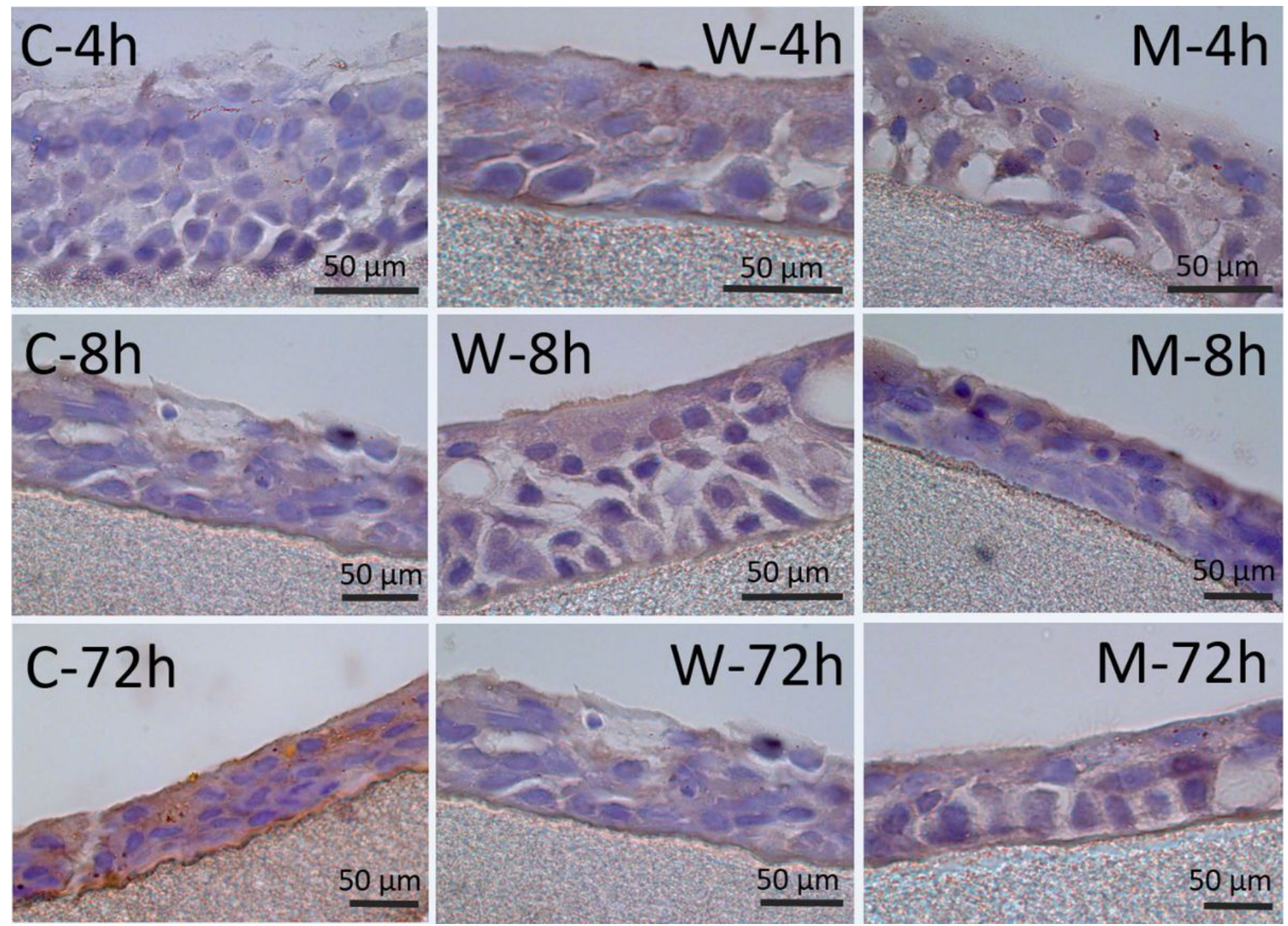

Figure 5

EpiAirway histology and haematosilin coloration under 1000x magnification: C - control group, W tissue exposed to the influence of particles collected in the woodworking industry, $M-$ tissue exposed to the influence of particles collected in the metalworking industry.

\section{Supplementary Files}

This is a list of supplementary files associated with this preprint. Click to download.

- 3.Highlights.doc 